\title{
Pengembangan Metode Pembelajaran Online Berbasis E-learning (Studi Kasus Mata Kuliah Bahasa Pemrograman)
}

\author{
Budi, Brian Nurjayanti \\ Program Keahlian Teknik Komputer, Program Diploma-IPB \\ tyasbudi@yahoo.com
}

Diterima 17 Maret 2012/Disetujui 18 September 2012

\begin{abstract}
E-learning method provides the ease and smoothness of the teaching-learning process for both students and lecturers. With e-learning methods, teachers can increase the intensity of interactive communication with students outside of official class hours. Elearning methods provide flexibility to the faculty to provide access to students to gain scientific references related to the course that may not be obtained during the hours of lecture and lab activities. These references may be scientific papers, popular articles or electronic journals. This would be particularly useful for students, because in addition to strengthening the understanding of students for each subject of the course, a reference of the international journals will greatly help to expand the students'knowledge, as well as improve their English. So hopefully in the future, IPB Diploma graduates, especially those who earn Programming Language course, will have high competitiveness in the global competition which is increasingly filled by graduates of foreign universities.
\end{abstract}

Keyword : e-learning, online, course, learning methods.

\section{Latar Belakang}

\section{PENDAHULUAN}

Mata kuliah Bahasa Pemrograman pada Program Diploma IPB khususnya pada Program Keahlian Teknik Komputer, merupakan salah satu mata kuliah yang menjadi dasar untuk pencapaian kompetensi utama. Mata kuliah ini memiliki kompetensi dasar yaitu mahasiswa akan dapat menggunakan bahasa pemrograman untuk menyelesaikan permasalahan-permasalahan dalam dunia nyata yang berhubungan dengan logika pemrograman. Pola pengajaran yang diberikan adalah penyampaian materi dan melakukan kegiatan membuat kode program dengan beberapa bahasa pemrograman (Prasetyo, 2006). Motivasi mahasiswa dalam mengikuti mata kuliah ini dapat dikatakan masih rendah dikarenakan kemampuan programming mahasiswa yang beragam. Hal ini berdampak terhadap penguasaan materi dan hasil atau produk yang dihasilkan masih belum da-pat terlihat. Semua hal diatas merupakan tantangan tersendiri bagi para pengajar untuk mengembangkan metode pembelajaran yang dapat memotivasi mahasiswa agar dapat menikmati dan nyaman mengikuti mata kuliah bahasa pemrograman sehingga mereka dapat menguasai materi dan dapat membuat produk berupa program komputer sederhana yang fungsional.

Seiring dengan semakin pesatnya perkembangan teknologi informa-si, penyebaran ilmu pengetahuan terutama di kalangan akademisi pun menjadi semakin cepat. Kegiatan transfer ilmu pengetahuan (knowledge transfer) pada universitasuniversitas terkemuka, dirasa tidak cukup hanya dengan mengandalkan tatap muka antara dosen dan mahasiswa. Hal ini pun disadari oleh tim pengajar mata kuliah bahasa pemrograman. Sistem pembelajaran dengan metode e-learning dirasa perlu diaplikasikan untuk melengkapi metode konvensional (tatap muka) untuk menumbuhkan motivasi belajar mahasiswa.

Metode e-learning (online course content) memberikan kemudahan dan kelancaran proses belajar-mengajar baik bagi mahasiswa maupun dosen (Wiliam, 2007). 
Dengan metode e-learning, dosen dapat meningkat-kan intensitas komunikasi interaktif dengan mahasiswa di luar jam kuliah resmi. Metode e-learning memberikan keleluasaan pada dosen untuk memberikan akses kepada mahasiswa untuk mendapatkan referensi ilmiah terkait dengan mata kuliah tersebut yang mungkin tidak didapat selama jam kuliah maupun praktikum. Referensi-referensi tersebut dapat berupa tulisan ilmiah, artikel populer atau jurnal-jurnal elektronik. Hal ini akan sangat berguna bagi mahasiswa, karena selain dapat memperkuat pema-haman mahasiswa untuk tiap pokok bahasan perkuliahan, referensi dari jurnal-jurnal internasional akan sangat membantu memperluas wawasan mahasiswa sekaligus meningkatkan kemampuan bahasa Inggris maha-siswa. Sehingga diharapkan di masa depan, para lulusan Diploma IPB, khususnya mereka yang memperoleh mata kuliah Bahasa Pemrograman, akan memiliki daya saing yang tinggi di pasar tenaga kerja yang semakin hari semakin banyak diisi oleh lulusan perguruan tinggi luar negeri.

\section{Tujuan}

Tujuan dari penelitian ini adalah : (1) Menerapkan metode pembelajaran berbasis E-learning, (2) Melakukan sosialisasi metode E-learning, (3) Menganalisis preferensi mahasiswa terhadap metode pembelajaran E-learning dikaitkan dengan atribut-atribut $E$ learning, (4) Memberikan rekomendasi penerapan metode E-learning berdasarkan analisa preferensi mahasiswa.

\section{Lokasi dan Waktu penelitian}

\section{METODE PENELITIAN}

Pengembangan metode pembelajaran online berbasis e-learning ini ditujukan untuk para mahasiswa diploma khususnya mahasiswa Program Keahlian Teknik Komputer. Pengembangan sistem ini dilakukan dilingkungan Program Diploma IPB.

\section{Jenis dan Sumber Data}

Pengembangan course content Bahasa Pemrograman berbasis E-learning ditujukan untuk penyajian informasi mata kuliah tersebut dengan informasi selengkaplengkapnya mulai dari materi kuliah sampai dengan materi ujian online. Data primer dan data sekunder yang dilibatkan dalam proses pengembangan course content diambil dari serangkaian materi kuliah dan praktikum dari para tim pengajar mata kuliah Bahasa Pemrograman dan dilakukan telaah serta dievaluasi kesesuaian materi tersebut dengan GBPP dan SAP perkuliahan.

Jenis data yang digunakan adalah data primer dan sekunder. Data primer diperoleh dari serangkaian materi kuliah dan praktikum dari para tim pengajar mata kuliah Bahasa Pemrograman dan dilakukan telaah serta dievaluasi kesesuaian materi tersebut dengan GBPP dan SAP perkuliahan. Data sekunder diperoleh dari studi di Perpustakaan LSI IPB, Departemen IImu Komputer, buku, internet, dan literatur-literatur lainnya yang terkait dengan topik penelitian.

Metode penarikan sampel yang digunakan dalam penelitian ini adalah non probability sampling, yaitu dengan metode convinience sampling. Peneliti sengaja mengelompokkan responden yang diteliti berdasarkan pengguna sistem yaitu mahasiswa, dan dosen. Lapisan sampel dibuat berdasarkan kriteria pengetahuan responden terhadap metode e-learning. Adapun jumlah sampel yang ditentukan berjumlah 325 responden, 310 orang responden mahasiswa, dan 15 orang responden dosen. 


\section{Metode Analisis Data}

Data yang terlibat dalam pengembangan online course content akan diolah dan diverifikasi dalam beberapa tahapan baik yang dilakukan secara manual maupun secara otomatis dilakukan oleh sistem. Analisis data secara manual dilakukan pada saat proses pendaftaran user pada e-learning Bahasa Pemrograman. Dengan acuan absensi kehadiran mahasiswa, maka jumlah serta identitas user yang mendaftar dapat dipantau dengan melihat item data yang menjadi acuan filterisasi yakni Nomor Induk Mahasiswa. Untuk mengukur tingkat efektifitas pengembangan course content berbasis e-learning juga dilakukan dengan penyebaran kuisioner kepada pengguna agar didapat kritik atau masukan terkait dengan penggunaan e-learning sebagai alternatif pembelajaran yang memiliki kendala dan tantangan tersendiri. Disamping itu kuisioner juga diberikan guna mendapatkan masukan dari para pengguna untuk penyempurnaan sistem yang lebih lanjut sehingga dapat diketahui apakah dengan metode pembelajaran alternatif ini dapat diterapkan pada mata kuliah lain.

Analisis data secara otomatis/komputerisasi dilakukan pada proses kegiatan ujian online dan perolehan nilai mahasiswa dari hasil ujian online tersebut. Mekanisme pembobotan soal dan penyajian ujian online yang dibatasi oleh waktu serta pengacakan terhadap soal ujian yang diakses dapat menjadi salah satu solusi mengatasi kelemahan kegiatan ujian online yakni indikasi terjadinya kecurangan yang dilakukan oleh peserta atau mahasiswa.

\section{HASIL DAN PEMBAHASAN}

\section{Hasil yang telah dicapai dari kegiatan yang sudah dilakukan}

Mengacu kepada jadwal pelaksanaan kegiatan pengembangan E-learning, maka dilakukan tahap persiapan bahan dan alat untuk melaksanakan kegiatan. Persiapan kegiatan meliputi beberapa tahap dengan tujuan akhir adalah memberikan rekomendasi pengembangan metode pembelajaran online berbasis e-learning untuk mata kuliah lainnya.

Melakukan pemilihan domain dan hosting untuk penempatan file-file aplikasi elearning sehingga dapat diakses secara online kapanpun dan dimanapun. Untuk dapat mengakses sebuah aplikasi online yang berjalan di internet, maka diperlukan proses pendaftaran nama domain dan menyimpan file-file aplikasinya disebuah server milik provider penyedia jasa layanan internet. Pemilihan nama domain dimaksudkan untuk penamaan alamat website yang nantinya para pengguna akan mengakses aplikasi elearning ini dengan mengetikkan alamat domain di sebuah browser internet (Arifin, 2005). Adapun nama domain yang didaftarkan untuk penerapan aplikasi e-learning ini diberi nama www.diplomaipb.web.id dan aplikasi e-learning dapat diakses di alamat www.diplomaipb.web.id/elearning.

Tahapan berikutnya adalah melakukan instalasi aplikasi e-learning termasuk kegiatan konfigurasi didalamnya. Berdasarkan account information dari pihak provider hosting, maka dilakukan proses instalasi aplikasi e-learning dengan mengirimkan file-file sumber ke server domain dimana prosesnya sering disebut sebagai proses upload file ke web server. Setelah dilaksanakan proses instalasi aplikasi e-learning, maka didapat halaman website yang berisi seluruh aktifitas dalam aplikasi e-learning (Gambar 1). 


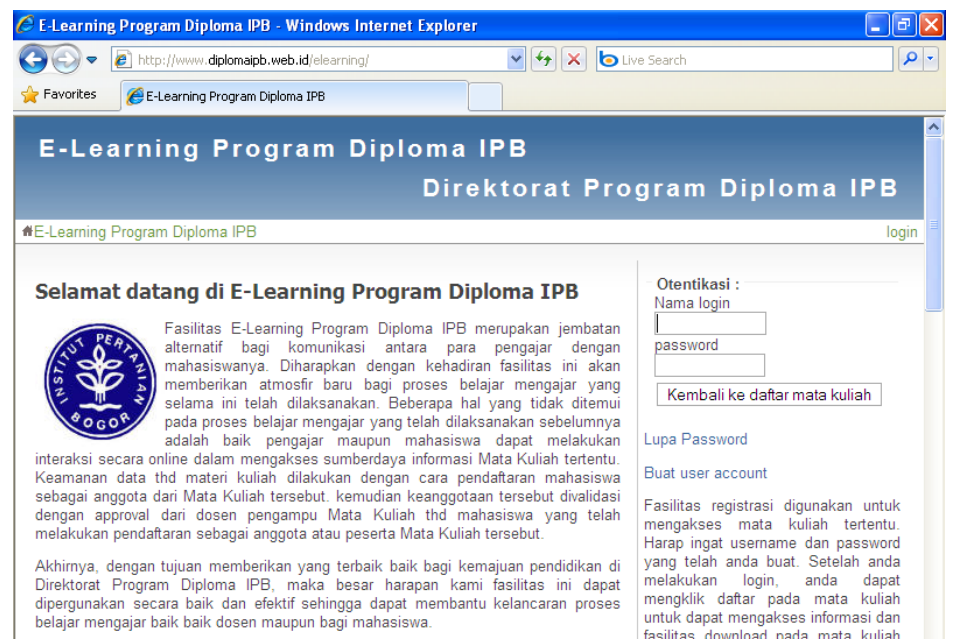

Gambar 1. Tampilan halaman website diplomaipb.web.id

Setelah dilakukan instalasi, selanjutnya dilakukan proses pengiriman konten aplikasi e-learning khususnya untuk mata kuliah Bahasa Pemrograman sebagai mata kuliah yang dijadikan sebagai studi kasus dalam penerapan e-learning di Program Diploma. Disamping itu dilakukan proses update isi dari aplikasi e-learning dengan materi perkuliahan mata kuliah Bahasa Pemrograman yang akan dijadikan sebagai studi kasus penerapan e-learning. Proses pengiriman materi perkuliahan mencakup bahan-bahan seperti materi presentasi kuliah, materi praktikum, GBPP Perkuliahan, SAP Perkuliahan dan bank soal untuk pelaksanaan ujian online (Gambar 2). Seluruh materi perkuliahan disimpan dalam sebuah link bernama dokumen-dokumen, dan kumpulan soal-soal ujian online disimpan dalam link Latihan-latihan.

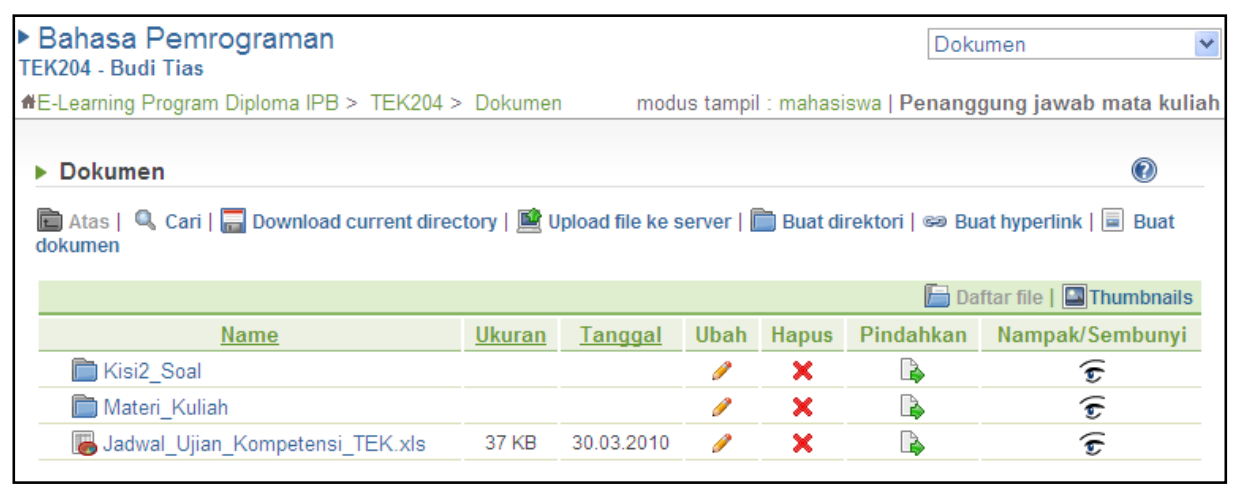

\section{Gambar 2. Tampilan halaman akses dokumen dan evaluasi online}

Tahap selanjutnya melakukan sosialisasi e-learning kepada para pengguna sistem yaitu para mahasiswa dan para dosen mata kuliah. Sasaran pembangunan aplikasi $e-$ learning ini adalah mahasiswa khususnya mahasiswa dari program keahlian teknik komputer. Untuk akses ke e-learning Diploma, setiap mahasiswa diwajibkan untuk mendaftar sebagai user baru di aplikasi tersebut. Tujuan dari pendaftaran adalah untuk proses verifikasi mahasiswa sebagai user yang terdaftar sebagai peserta mata kuliah Bahasa Pemrograman. Teknik verifikasi yang dilakukan adalah dengan melihat tiga parameter penting pada saat user melakukan pendaftaran, yakni nama mahasiswa, NIM 
dan nomor HP. Kemudian data yang telah disimpan segera dicocokan dengan absensi kehadiran mahasiswa di BAP perkuliahan dari mata kuliah Bahasa Pemrograman.

Salah satu bentuk sosialisasi metode pembelajaran yang dilakukan adalah melakukan proses evaluasi belajar secara online yakni melibatkan mahasiswa dalam pelaksanaan evaluasi belajar dengan pemanfaatan aplika-si e-learning ini untuk mendapatkan nilai akhir dan kelulusan pada mata kuliah Bahasa Pemrograman. Salah satu kelebihan dari metode evaluasi belajar online ini adalah hasil evaluasi dapat langsung dilihat oleh mahasis-wa yang bersangkutan setelah selesai menjawab seluruh soal yang diujikan (Burgos, 2006). Adapun jenis soal yang diujikan pada evaluasi belajar online ini menggunakan pilihan ganda dengan jawaban unik atau multiple choice single answer (Gambar 3). Untuk mengantisipasi kecurangan selama ujian online berlangsung, maka dilakukan randomisasi soal pada bank soal yang tersedia.

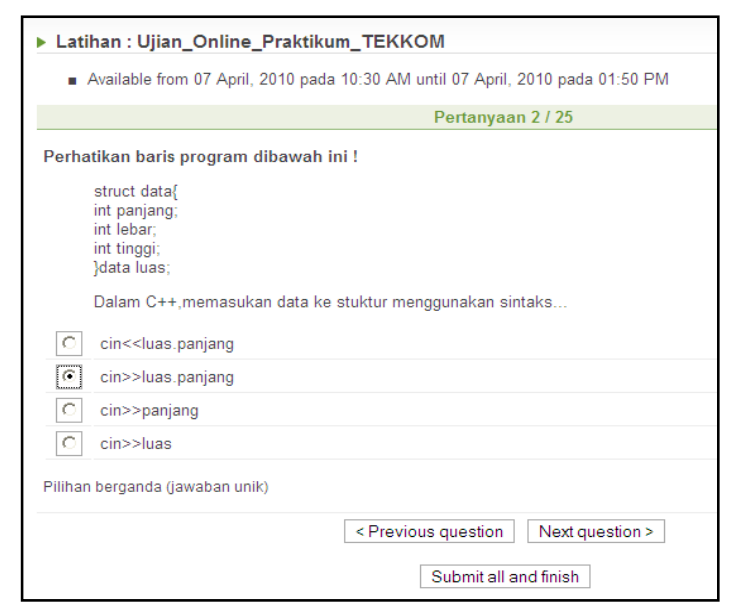

\section{Gambar 3. Tampilan halaman akses evaluasi online}

Pada tahap akhir penelitian dilakukan analisis kuisioner untuk mengetahui preferensi mahasiswa terhadap penerapan metode e-learning. Hasil analisa yang dilakukan akan digunakan sebagai rujukan berupa rekomendasi metode pembelajaran $E$ learning kepada pihak institusi sehingga ke depannya metode pembelajaran ini dapat diterapkan pada mata kuliah yang lain.

Pada mahasiswa yang sudah mengetahui e-learning dan pernah melaksanakan ujian online, menggunakan sampel 310 responden. 58\% responden menyatakan metode e-learning dapat memberikan kemudahan belajar untuk mahasiswa untuk mendapatkan materi secara online dan mengumpulkan tugas. $20 \%$ responden menyatakan dukungan sarana lab komputer yang sudah baik juga sangat membantu metode pembelajaran online. $18 \%$ responden menyatakan dukungan teknologi berupa learning tools terinstall juga memudahkan mahasiswa memahami metode tersebut.

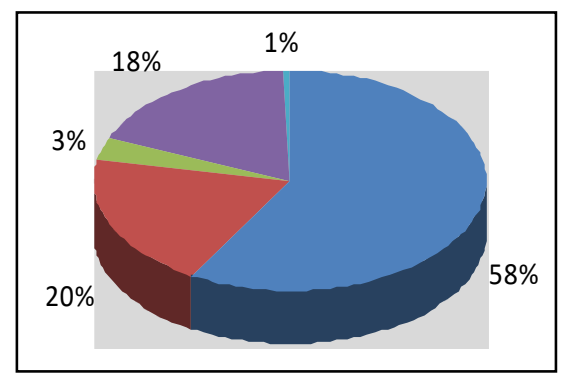

Gambar 1 Mahasiswa yang sudah mengenal e-learning 
Responden mahasiswa yang belum pernah menggunakan e-learning survey dilakukan dengan menggunakan 50 responden. $66 \%$ responden menyatakan e-learning dapat memberi-kan kemudahan untuk mendapatkan materi karena sifat dokumen yang berupa softcopy baik yang berformat *.doc, *.ppt dan *.pdf. 31\% responden menyatakan e-learning berkaitan dengan teknologi karena perkembangan teknologi yang semakin maju. Dan 3\% responden menyatakan kalau e-learning identik dengan lab komputer sebagai sarana pendukungnya.

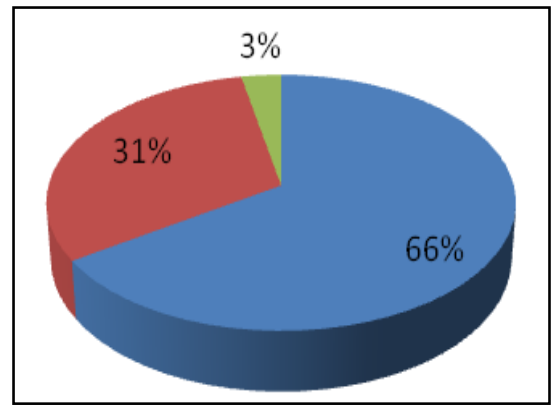

Gambar 2. Mahasiswa yang belum pernah menggunakan e-learning

Sedangkan pada responden dosen diploma IPB, survey dilakukan dengan 50 responden. $50 \%$ responden menyatakan e-learning berhubungan dengan penggunaan teknologi internet. Hal ini dimungkinkan karena metode ini dijalankan dengan menggunakan teknologi internet. $25 \%$ para dosen menyoroti perbaikan sarana pendukung metode pembelajaran tersebut. Dan $13 \%$ para dosen menyoroti koneksi internet yang sudah baik akan mendukung keberhasilan metode pembelajaran online tersebut. $12 \%$ responden menyatakan bahwa metode pembelajaran online akan membantu aktifitas dosen dalam proses belajar dan mengajar dan mempermudah penyampaian materi.

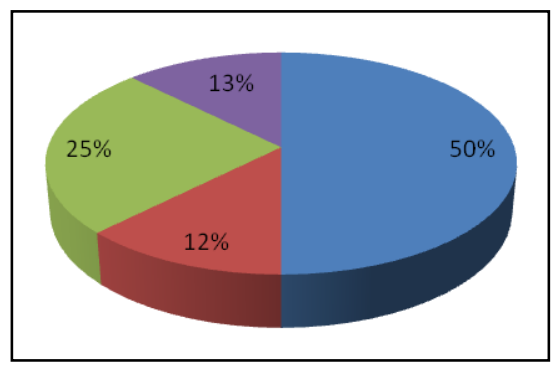

Gambar 3. Persepsi Dosen diploma IPB terhadap e-learning

Survey terhadap 310 responden terkait mekanisme pelaksanaan metode pembelajaran online berbasis e-learning memberikan kesimpulan sebagai berikut. $63 \%$ responden menyoroti perbaikan kualitas untuk mendukung mekanisme metode pembelajaran online. Perbaikan kualitas itu diantaranya menghindari virus komputer, error pada server, koneksi yang kurang cepat, tampilan e-learning, memperbanyak jumlah komputer, memberikan informasi benar salah, bahasa soal yang tidak ambigu, dan memberikan timer pada ujian online. $24 \%$ responden menginginkan ujian online dilakukan secara online dan sebanyak $2 \%$ menghendaki ujian tetap dilaksanakan secara manual. $7 \%$ responden menyatakan bahwa perlu dilakukan sosialisasi sesering mungkin pada metode pembelajaran online. $3 \%$ responden menyatakan metode pembelajaran online ini idealnya diterapkan pada semua mata kuliah. Sebanyak $1 \%$ responden 
menyatakan kekuatiran akan hasil evaluasi belajar mahasiswa yang jelek akibat pelaksanaan metode pembelajaran online ini khususnya untuk kegiatan evaluasi belajar online.

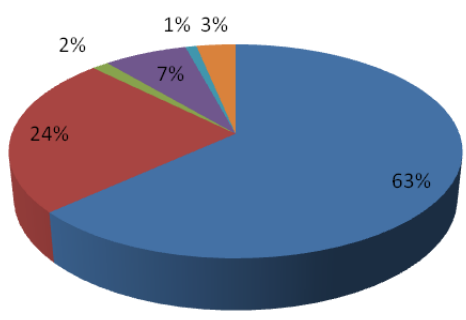

Gambar 4. Mekanisme pelaksanaan metode pembelajaran online berbasis e-learning

\section{Kendala pengembangan metode pembelajaran online berbasis e-learning}

Aplikasi e-learning berjalan baik dilingkungan internet. Sehubungan dengan banyaknya user yang mengakses aplikasi e-learning dalam waktu bersamaan khususnya ketika melakukan ujian online, maka seharusnya koneksi internet untuk keperluan kegiatan ini harus bersifat dedicated line. Solusi dari masalah tersebut untuk sementara dapat dilangsungkan kegiatan ujian online dengan menggunakan server lokal yang terhubung dalam suatu jaringan LAN (Arifin, 2005)

Untuk dapat memperkenalkan dan menerapkan aplikasi e-learning di Program Diploma, perlu dilakukan secara bertahap. Mulai dari pihak yang terlibat langsung dalam e-learning (dalam hal ini adalah mahasiswa dan dosen mata kuliah bersangkutan) sampai kepada pihak yang tidak terlibat secara langsung (pihak pengelola Program Diploma - IPB).

\section{Simpulan}

\section{SIMPULAN DAN SARAN}

Pengembangan metode pembelajaran e-learning telah disosialisasikan serta dilaksanakan oleh mahasiswa terutama pada program keahlian Teknik Komputer dan Manajemen Informatika.

Metode pembelajaran ini telah dapat membangun pola fikir komunikasi yang komprehensif dan interaktif kepada mahasiswa, dosen dan segenap sivitas akademika dan dapat dijadikan metode pembelajaran alternatif karena dirasakan cukup efektif dan efisien baik dari segi pelaksanaan maupun evaluasi pembelajrannya

Metode pembelajaran e-learning telah dapat menjadi media informasi yang dapat diakses oleh civitas akademika program diploma tanpa batas waktu, jarak dan wilayah geografis.

Pengembangan metode pembelajaran berbasis e-learning dapat dengan baik dilaksanakan jika didukung oleh ketersediaan sarana dan prasarana jaringan yang menunjang serta sosialisasi metode tersebut kepada seluruh civitas akademika di Program Diploma - IPB.

\section{Saran}

Perlu ditinjau kecepatan koneksi internet yang tersedia agar pelaksanaan motede pembelajaran berbasis e-learning dapat berjalan lancar. Salah satu solusinya adalah dengan melakukan instalasi aplikasi e-learning ditingkat komputer lokal mengingat infrastruktur jaringan telah dibangun di tiap lab komputer yang ada. 
Perlu dilakukan serangkaian pelatihan dalam rangka sosialisasi pengembangan metode pembelajaran berbasis e-learning ini agar segenap civitas akademika memiliki pola pemikiran efektif dan menerima e-learning menjadi salah satu alternatif metode pembelajaran dan evaluasi dalam kegiatan perkuliahan

\section{DAFTAR PUSTAKA}

Arifin, J. Jaringan Komputer. Penerbit Andi. 2005.

Burgos, D. \& Specht, M. Adaptive e-learning Methods and IMS Learning Design: An Integrated Approach Proc. Sixth Int Advanced Learning Technologies Conf, 2006.

Prasetyo, D.D. 101 Tip \& Trik Pemrograman PHP. Elex Media Komputindo. 2006.

Williams, B K., Stacey C S. Using Information Technology. Pengenalan Praktis Dunia Komputer dan Komunikasi. 7nd Edition. Penerbit Andi. Yogyakarta. 2007. 